\title{
PENGARUH MOTIVASI DAN DISIPLIN BELAJAR TERHADAP HASIL BELAJAR MATA PELAJARAN PRAKARYA DAN KEWIRAUSAHAAN
}

\author{
Rufi Indrianti ${ }^{1}$, Sutrisno Djaja ${ }^{1}$, Bambang Suyadi ${ }^{1}$ \\ ${ }^{1}$ Program Studi Pendidikan, Fakultas Keguruan dan Ilmu Pendidikan, Universitas Jember \\ e-mail: sutrisnodjaja.fkip@unej.ac.id
}

\begin{abstract}
Abstrak
Penelitian ini dilakukan untuk mengetahui pengaruh yang signifikan dari motivasi dan disiplin belajar terhadap hasil belajar mata pelajaran prakarya dan kewirausahaan (studi kasus siswa kelas X program keahlian akuntansi SMK Negeri 1 Bondowoso tahun ajaran 2016/2017). Metode penentuan lokasi penelitian menggunakan metode purposive area yaitu di SMK Negeri 1 Bondowoso. Penentuan jumlah responden dalam penelitian ini menggunakan metode populasi yaitu sebanyak 59 responden. Metode pengumpulan data yang digunakan terdiri dari metode: angket, wawancara, observasi, dan dokumen. Analisis data yang digunakan adalah analisis deskriptif dan analisis inferensial/statistik yaitu dengan menggunakan analisis garis regresi regresi linear berganda, analisis varian garis regresi, uji F, dan uji t. Hasil penelitian menunjukkan bahwa analisis regresi linear berganda menghasilkan persamaan $\hat{Y}=46,903+0,804+0,897+$ dengan nilai R square sebesar 0,804 . Hasil uji F antara Fhitung dengan Ftabel yaitu nilai Fhitung $=115,080>$ Ftabel $=3,162$ dengan tingkat signifikansi $\mathrm{F}=0,000<\mathrm{a}=0,05$, maka Ho ditolak. Hasil uji t hitung dengan ttabel yaitu thitung sebesar 6,957 $>$ ttabel sebesar 2,003 pada taraf signifikansi $\mathrm{t}=0,000<\alpha=0.05$, dengan kriteria pengujian yaitu thitung > ttabel, maka Ho ditolak. Hal tersebut menunjukkan bahwa ada pengaruh yang signifikan variabel motivasi dan disiplin belajar terhadap hasil dengan besaran pengaruh sebesar 80,4 \%, dengan rincian proporsi sumbangan variabel motivasi belajar terhadap hasil belajar sebesar 43,9944 \% dan proporsi sumbangan variabel disiplin belajar terhadap hasil belajar sebesar 36,4998 \%. Berdasarkan hasil perhitungan tersebut maka dapat disimpulkan bahwa variabel bebas motivasi belajar merupakan variabel yang paling dominan mempengaruhi variabel terikat yaitu hasil belajar yaitu sebesar 43,9944\%, sedangkan sisanya yaitu 19,6\% dipengaruhi variabel bebas lainnya yang tidak diteliti dalam penelitian ini seperti lingkungan sekolah, lingkungan masyarakat, keadaan keluarga, faktor psikologis (intelegensi, perhatian, minat), dan lain-lain.
\end{abstract}

Kata Kunci: Motivasi belajar, disiplin belajar dan hasil belajar

\section{PENDAHULUAN}

Kegiatan belajar adalah kegiatan primer, sedangkan mengajar merupakan kegiatan sekunder yang dimaksudkan untuk dapat terjadi kegiatan belajar yang optimal. Kegiatan belajar merupakan proses pendidikan yang sebagian besar terjadi di sekolah. Ini berarti bahwa berhasil tidaknya pencapaian tujuan pendidikan banyak bergantung kepada bagaimana pencapaian taksonomi pendidikan yang dialami siswa yang mencakup aspek kognitif, afektif dan psikomotorik.

Dalam suatu lembaga pendidikan keberhasilan proses belajar mengajar dapat dilihat dari hasil belajar yang dicapai oleh peserta didik. Keberhasilan pembelajaran di sekolah akan terwujud dari keberhasilan belajar siswa. Untuk mencapai keberhasilan dalam sebuah proses belajar dilihat dari hasil belajar yang optimal. Hasil belajar optimal ini dipengaruhi oleh dua faktor, yaitu faktor internal dan faktor eksternal. Faktor internal adalah faktor yang ada dalam diri individu, sedangkan faktor eksternal adalah faktor yang ada diluar individu. Faktor - faktor yang mempengaruhi hasil belajar tersebut terdiri dari kecerdasan, bakat, minat dan perhatian, motivasi, kesehatan, cara belajar, disiplin, lingkungan keluarga, lingkungan pergaulan, sekolah dan sarana pendukung.

Dalam penelitian ini peneliti mengambil dua faktor yang mempengaruhi hasil belajar siswa, yakni motivasi dan disiplin belajar siswa. Motivasi belajar merupakan salah satu faktor yang penting yang mempengaruhi belajar dan hasil belajar siswa, karena siswa yang memiliki motivasi cenderung untuk mencurahkan segala kemampuannya untuk menghasilkan hasil belajar yang optimal sesuai 
dengan hasil belajar yang diharapkan. Semakin tinggi motivasi yang dimiliki siswa akan mendorong siswa tersebut untuk belajar lebih giat dan frekuensi belajarnya akan semakin meningkat.

Motivasi belajar siswa dapat menjadi lemah, lemahnya motivasi atau tiadanya motivasi belajar akan melemahkan kegiatan, sehingga mutu hasil belajar menjadi rendah. Oleh karena itu motivasi belajar pada diri siswa perlu diperkuat terus menerus, dengan tujuan agar siswa mempunyai motivasi belajar yang kuat, sehingga hasil belajar yang diperolehnya dapat optimal. Motivasi belajar yang dimiliki oleh siswa dalam setiap kegiatan pembelajaran sangat berperan untuk meningkatkan hasil belajar siswa dalam mata pelajaran tertentu. Siswa yang memiliki motivasi terhadap suatu pelajaran akan lebih mudah memahami apa yang telah dipelajari dalam pelajaran tersebut. Siswa akan menghargai apa yang telah dipelajari sehingga merasakan kegunaannya dalam kehidupan sehari-hari di tengah-tengah masyarakat.

Menurut Uno (2011:9) motivasi merupakan suatu dorongan yang timbul oleh adanya rangsangan dari dalam maupun dari luar sehingga seseorang berkeinginan untuk mengadakan perubahan tingkah laku atau aktivitas tertentu lebih baik dari sebelumnya. Menurut Uno (2011 : 23) indikator motivasi belajar siswa terdiri dari adanya hasrat dan keinginan berhasil, adanya dorongan dan kebutuhan dalam belajar, adanya harapan atau cita-cita masa depan, adanya penghargaan dalam belajar, adanya kegiatan yang menarik dalam belajar, serta adanya lingkungan belajar yang kondusif.

Selain motivasi keberhasilan belajar mengajar juga dipengaruhi oleh disiplin belajar siswa. Proses belajar mengajar guru yang berhadapan dengan sejumlah peserta didik dengan berbagai macam latar belakang, sikap dan potensi, yang kesemuanya itu berpengaruh terhadap kebiasaannya dalam mengikuti pembelajaran dan berperilaku di sekolah. Kebiasaan itu masih banyak yang tidak mendukung bahkan menghambat pembelajaran, misalnya tidak mengerjakan tugas rumah, membuat keributan di kelas dan lainnya sehingga kondisi tersebut menuntut guru untuk senantiasa mendisiplinkan siswa agar dapat mendongkrak kualitas pembelajaran.

Menurut Komensky dalam Koesoema (2015:236) disiplin merupakan proses pengajaran, pelatihan, seni mendidik, dan materi kedisiplinan dalam sekolah. Sedangkan menurut Farida (2014: 67) disiplin merupakan tindakan yang sesuai dengan prosedur yang telah ditetapkan. Kedisiplinan sekolah erat hubungannya dengan kerajinan siswa dalam sekolah dan juga dalam belajar.

Pengelolaan pengajaran di kelas tidak akan berjalan dengan baik tanpa adanya kesadaran melaksanakan aturan yang sudah ditentukan sebelumnya. Misalnya, kesepakatan peraturan antara guru dan murid sebelum pengajaran dimulai beserta sanksi yang akan didapat apabila ada yang melanggar. Disiplin tersebut meliputi : disiplin siswa selama pelajaran berlangsung, disiplin siswa pada waktu mengerjakan ulangan, disiplin siswa pada saat mengumpulkan tugas, dan disiplin siswa pada saat menggunakan fasilitas belajar di sekolah. Dengan adanya kesepakatan itu diharapkan kelas akan menjadi kondusif, terarah dan teratur.

Sikap disiplin merupakan salah satu faktor yang dapat mempengaruhi hasil belajar. Apabila seorang siswa memiliki sikap disiplin dalam kegiatan belajarnya, maka kepatuhan dan ketekunan belajarnya akan terus meningkat sehingga membuat hasil belajarnya meningkat. Jadi apabila siswa memiliki sikap disiplin yang tinggi dalam kegiatan belajar mengajar tentunya hasil belajar yang diperoleh menjadi baik. Sebaliknya jika siswa tidak memiliki sikap disiplin dalam belajar maka kegiatan belajarnya tidak terencana dengan baik sehingga kegiatan belajarnya tidak teratur dan membuat hasil belajarnya menurun.

Menurut Dimyati dan Mujiono (2015:200) hasil belajar adalah tingkat keberhasilan yang dicapai oleh siswa setelah mengikuti suatu kegiatan pembelajaran, dimana tingkat keberhasilan yang dicapai oleh siswa setelah mengikuti suatu kegiatan pembelajaran, dimana tingkat keberhasilan tersebut ditandai dengan skala nilai berupa huruf atau kata atau simbol. 
Motivasi dan disiplin belajar merupakan faktor yang penting untuk memperoleh hasil belajar yang optimal. Dengan adanya motivasi belajar dan diikuti disiplin belajar yang tinggi maka akan diperoleh hasil belajar yang tinggi pula, begitu juga dengan sebaliknya. Motivasi akan membentuk kesadaran dan disiplin belajar akan berpengaruh terhadap cara dan sikap belajar yang akhirnya akan diperoleh hasil belajar.

Fenomena yang terjadi sekarang ini di SMK Negeri 1 Bondowoso dalam proses pembelajaran di kelas secara umum terlihat siswa mempunyai motivasi belajar yang baik. Hal tersebut ditunjukkan dengan sikap yang antusias dalam mengikuti pelajaran, misalnya memperhatikan penjelasan guru, mencatat hal-hal penting yang disampaikan guru, aktif bertanya terkait materi yang kurang dipahami, dan antusias saat mengikuti praktek prakarya serta menerapkan ilmu kewirausahaan yang telah dipelajari dengan menjual hasil kerajinan yang telah dibuat.

Disiplin belajar yang dimiliki siswa kelas X Program keahlian Akuntansi SMK Negeri 1 Bondowoso sangat bervariatif, hal ini terlihat dari disiplin dalam menaati tata tertib, mengumpulkan tugas tepat waktu dan ada beberapa siswa yang terlihat kurang disiplin dalam mengumpulkan tugas yang diberikan guru serta terlambat masuk kelas.

Penelitian ini memilih SMK Negeri 1 Bondowoso mata pelajaran prakarya dan kewirausahaan kelas X program keahlian akuntansi karena dalam mata pelajaran tersebut siswa diajarkan materi sekaligus praktek langsung dalam pembuatan dan penjualan barangnya, sehingga anak lulusan SMK 1 akan memliki kemampuan lain disamping ilmu yang sesuai penjurusannya dan program keahlian akuntansi merupakan salah satu program keahlian yang sangat diminati disana, siswa dalam program keahlian tersebut dikenal dengan siswa yang memiliki kemampuan akademik yang baik sehingga guru akan lebih mudah dalam menyampaikan materi. Selain itu, di SMK 1 Bondowoso telah memiliki sarana dan prasarana yang baik seperti penggunaan LCD disetiap kelas, jumlah siswa yang ideal disetiap kelasnya, serta akses wifi sehingga akan menunjang terjadinya proses pembelajan yang baik dan efektif.

\section{METODE}

Penelitian ini merupakan penelitian deskriptif kuantitatif, yaitu untuk mengetahui pengaruh motivasi dan disiplin belajar mata pelajaran prakarya dan kewirausahaan (studi kasus siswa kelas X program keahlian akuntansi SMK Negeri 1 Bondowoso tahun ajaran 2016/2017). Metode penentuan lokasi penelitian menggunakan metode purposive area yaitu di SMK Negeri 1 Bondowoso. Penentuan jumlah responden dalam penelitian ini menggunakan metode populasi yaitu sebanyak 59 responden. Metode pengumpulan data yang digunakan terdiri dari metode: angket, wawancara, observasi, dan dokumen. Uji instrumen data dalam penelitian ini menggunakan uji validitas dan uji reliabilitas. Teknik pengolahan data dalam penelitian ini menggunakan editing, skoring, dan tabulasi. Analisis data yang digunakan adalah analisis deskriptif dan analisis inferensial/statistik yaitu dengan menggunakan analisis garis analisis regresi linear berganda dengan rumus sebagai berikut:

$$
\hat{\mathrm{Y}}=\mathrm{a}+\mathrm{b}_{1} \mathrm{X}_{1}+\mathrm{b}_{2} \mathrm{X}_{2}
$$

Untuk analisis varian garis regresi yaitu untuk mengetahui kuat tidaknya atau tingkat keeratan variabel motivasi dan disiplin belajar mata pelajaran prakarya dan kewirausahaan (studi kasus siswa kelas X program keahlian akuntansi SMK Negeri 1 Bondowoso tahun ajaran 2016/2017) yaitu dengan rumus sebagai berikut:

$$
\operatorname{Ry}(1,2)=\sqrt{\frac{a 1 \sum X 1 Y+a 2 \sum X 2 Y}{\sum Y^{2}}}
$$


Sedangkan uji $\mathrm{F}$ yaitu untuk mengetahui pengaruh yang signifikan variabel motivasi dan disiplin belajar mata pelajaran prakarya dan kewirausahaan (studi kasus siswa kelas X program keahlian akuntansi SMK Negeri 1 Bondowoso tahun ajaran 2016/2017), yaitu dengan rumus sebagai berikut:

$$
\mathrm{F}_{\mathrm{h}}=\frac{R^{2} / K}{\left(1-R^{2} /(n-k-1)\right.}
$$

Selanjutnya, untuk Uji t diguanakan untuk menguji hipotesis dari variabel motivasi dan disiplin belajar mata pelajaran prakarya dan kewirausahaan (studi kasus siswa kelas X program keahlian akuntansi SMK Negeri 1 Bondowoso tahun ajaran 2016/2017), yaitu dengan rumus sebagai berikut:

$$
t=\frac{\mathrm{p} \sqrt{\mathrm{n}-3}}{\sqrt{1}-\mathrm{rp} 2}
$$

\section{HASIL DAN PEMBAHASAN}

Berdasarkan hasil analisis garis regresi sederhana diperoleh $\mathbf{R}_{\text {square }}$ sebesar 0,804 . Koefisien determinasi $\mathbf{R}_{\text {square }}$ dalam penelitian ini digunakan untuk mengukur besarnya pengaruh variabel bebas (X) dan variabel terikat (Y). Jenis analisis ini digunakan untuk mengetahui pengaruh yang signifikan dari variabel bebas yaitu motivasi dan disiplin belajar mata pelajaran prakarya dan kewirausahaan (studi kasus siswa kelas X program keahlian akuntansi SMK Negeri 1 Bondowoso tahun ajaran 2016/2017). Berdasarkan analisis data yang dilakukan diperoleh hasil dalam tabel berikut ini:

\begin{tabular}{|c|c|c|c|c|c|c|c|}
\hline \multirow{2}{*}{ Variabel } & \multicolumn{2}{|c|}{$\mathrm{F}_{\mathrm{Hitu}}$} & \multirow{2}{*}{\multicolumn{2}{|c|}{$\mathrm{F}^{\mathrm{Sig}}$}} & \multirow{2}{*}{$A$} & & \multirow{2}{*}{ Square } \\
\hline & $\mathrm{ng}$ & Tabel & & & & & \\
\hline $\mathrm{X}$ terhadap & & & 0,0 & & 0 & & 0 \\
\hline $\mathrm{Y}$ & 080 &, 162 & 00 & ,05 & &, $897^{\mathrm{a}}$ & ,804 \\
\hline
\end{tabular}

Tabel Ringkasan Uji F, Multiple R, dan R Square

Sumber : Data diolah 2017

Tabel di atas menunjukkan bahwa $\mathrm{F}_{\text {hitung }}=115,080>\mathrm{F}_{\text {tabel }}=3,162$ dengan tingkat signifikansi $\mathrm{F}=0,000<a=0,05$. Hal ini menunjukkan bahwa variabel motivasi dan disiplin belajar memiliki pengaruh yang signifikan terhadap hasil belajar siswa pada mata pelajaran prakarya dan kewirausahaan (studi kasus siswa kelas X program keahlian akuntansi SMK Negeri 1 Bondowoso tahun ajaran 2016/2017). Untuk koefisien determinasi $R_{\text {Square }}$ sebesar 0,804, yang dengan proporsi sumbangan variabel X terhadap Y sebesar $80,4 \%$. sedangkan sisanya yaitu $19,6 \%$ dipengaruhi variabel bebas lainnya yang tidak diteliti dalam penelitian ini seperti lingkungan sekolah, lingkungan masyarakat, keadaan keluarga, faktor psikologis (intelegensi, perhatian, minat), dan lain-lain (Slameto (2010:54). Hubungan antara motivasi dan disiplin belajar mata pelajaran prakarya dan kewirausahaan (studi kasus siswa kelas X program keahlian akuntansi SMK Negeri 1 Bondowoso tahun ajaran 2016/2017) dapat diketahui dari multiple $\mathrm{R}$ sebesar 0,897 dengan kategori hubungan yang sangat kuat.

Pembahasan

Hasil belajar siswa yang optimal merupakan harapan dari setiap siswa, guru dan orang tua. Hasil belajar diperlukan dalam pertimbangan untuk menentukan kenaikan kelas dan kelulusan. Namun antara siswa satu dengan siswa yang lainnya berbeda dalam pencapaian hasil belajar. Adanya perbedaan hasil belajar siswa dipengaruhi oleh dua faktor yaitu faktor internal dan faktor eksternal. Faktor internal yaitu faktor yang bersumber dari dalam individu seperti kecerdasan, perhatian, minat, bakat, motivasi, kematangan, dan kesiapan. Sedangkan faktor eksternal adalah semua faktor yang bersumber dari luar seperti lingkungan keluarga, lingkungan sekolah, dan lingkungan masyarakat. 
Seorang siswa harus mempunyai motivasi belajar yang tinggi untuk menggerakkan semangat belajarnya. Siswa yang mempunyai motivasi tinggi akan selalu terdorong untuk belajar secara giat, sehingga keberhasilan akan mudah dicapai. Hal ini sesuai dengan pendapat sardiman (2005:85) motivasi akan senantiasa menentukan intensitas usaha belajar bagi para siswa.

Berdasarkan hasil temuan yang dilakukan secara parsial dengan uji t, dapat diketahui bahwa variabel bebas motivasi belajar berpengaruh secara nyata terhadap variabel terikat hasil belajar. Hal ini dibuktikan pada perhitungan $\mathrm{t}_{\text {hitung }}$ sebesar 8,013>t tabel sebesar 2,003 dan $\alpha=0.05>\operatorname{sig} \mathrm{t}=0.000$, maka motivasi belajar mempunyai pengaruh yang signifikan terhadap hasil belajar siswa.

Hasil belajar siswa dapat dipengaruhi oleh motivasi belajar. Motivasi belajar akan mendorong siswa untuk mencapai hasil belajarnya. Sesuai dengan pendapat Sardiman (2005:84-85) motivation is an essential condition of learning. Hasil belajar akan menjadi optimal, kalau ada motivasi. Makin tepat motivasi yang diberikan, akan makin berhasil pula pelajaran itu. Jadi motivasi akan senantiasa menentukan intensitas usaha belajar bagi para siswa.Hal ini sejalan dengan pendapat Hamalik (2014:179) motivasi itu sangat penting dalam menentukan kegiatan belajar mengajar. Bila remaja tidak punya motivasi, maka guru tidak menjamin penempatan siswa di kelas tertentu, baik kegiatan belajarnya maupun keberhasilannya.

Indikator motivasi belajar dalam penelitian ini antara lain adanya hasrat dan keinginan berhasil, adanya dorongan dan kebutuhan dalam belajar, adanya harapan dan cita-cita masa depan, adanya penghargaan dalam belajar, adanya kegiatan yang menarik dalam belajar, adanya lingkungan belajar yang kondusif. Hasil belajar yang maksimal diperoleh apabila siswa mempunyai motivasi belajar yang tinggi.

Selain motivasi keberhasilan belajar mengajar juga dipengaruhi oleh disiplin belajar siswa. Proses belajar mengajar guru yang berhadapan dengan sejumlah peserta didik dengan berbagai macam latar belakang, sikap dan potensi, yang kesemuanya itu berpengaruh terhadap kebiasaannya dalam mengikuti pembelajaran dan berperilaku di sekolah. Kebiasaan itu masih banyak yang tidak mendukung bahkan menghambat pembelajaran, misalnya tidak mengerjakan tugas rumah, membuat keributan di kelas dan lainnya sehingga kondisi tersebut menuntut guru untuk senantiasa mendisiplinkan siswa agar dapat mendongkrak kualitas pembelajaran.

Pengelolaan pengajaran di kelas tidak akan berjalan dengan baik tanpa adanya kesadaran melaksanakan aturan yang sudah ditentukan sebelumnya. Misalnya, kesepakatan peraturan antara guru dan murid sebelum pengajaran dimulai beserta sanksi yang akan didapat apabila ada yang melanggar. Disiplin tersebut meliputi : disiplin siswa selama pelajaran berlangsung, disiplin siswa pada waktu mengerjakan ulangan, disiplin siswa pada saat mengumpulkan tugas, dan disiplin siswa pada saat menggunakan fasilitas belajar di sekolah. Dengan adanya kesepakatan itu diharapkan kelas akan menjadi kondusif, terarah dan teratur.

Sikap disiplin merupakan salah satu faktor yang dapat mempengaruhi hasil belajar. Apabila seorang siswa memiliki sikap disiplin dalam kegiatan belajarnya, maka kepatuhan dan ketekunan belajarnya akan terus meningkat sehingga membuat hasil belajarnya meningkat. Jadi apabila siswa memiliki sikap disiplin yang tinggi dalam kegiatan belajar mengajar tentunya hasil belajar yang diperoleh menjadi baik. Sebaliknya jika siswa tidak memiliki sikap disiplin dalam belajar maka kegiatan belajarnya tidak terencana dengan baik sehingga kegiatan belajarnya tidak teratur dan membuat hasil belajarnya menurun. Hal ini sejalan dengan pendapat Hamalik (2014:108) perilaku tak disiplin siswa pada akhirnya akan menimbulkan akibat-akibat yang tidak menguntungkan, baik bagi pribadi anak maupun bagi pelaksanaan pendidikan di sekolah. Kerugian bagi anak ialah karena suasana itu justru menumbuhkan perilaku yang merugikan dan tak bertanggung jawab, yang pada gilirannya akan mempengaruhi perkembangan pribadi mereka. Kerugian bagi praktik pendidikan ialah karena 
menyebabkan suasana lingkungan belajar menjadi kurang menarik dan menumbuhkan gangguan belajar yang pada gilirannya akan mempengaruhi keberhasilan dan kemajuan belajar anak-anak serta menumbuhkan perilaku yang destruktif lainnya. Hal ini sejalan dengan pendapat Khasanah dalam Kusuma (2015:169) semakin tinggi disiplin belajar siswa maka hasil belajarnya akan semakin tinggi pula.

Berdasarkan hasil temuan yang dilakukan secara parsial dengan uji t, dapat diketahui bahwa variabel bebas disiplin belajar berpengaruh secara nyata terhadap variabel terikat hasil belajar. Hal ini dibuktikan pada perhitungan $t_{\text {hitung }}$ sebesar 6,957 > tabel sebesar 2,003 dan $\alpha=0.05>\operatorname{sig} t=0.000$, maka disiplin belajar mempunyai pengaruh yang signifikan terhadap hasil belajar siswa.

Indikator disiplin belajar dalam penelitian ini adalah disiplin siswa dalam masuk sekolah, disiplin siswa serius mengikuti pelajaran, disiplin siswa saat mengerjakan tugas, disiplin siswa dalam menggunakan fasilitas belajar di sekolah.

Hasil analisis Koefisien Determinasi $\left(\mathrm{R}^{2}\right)$ yang digunakan untuk mengetahui konstribusi atau besarnya pengaruh variabel bebas yaitu motivasi dan disiplin belajar siswa terhadap variabel terikat yaitu hasil belajar sebesar 43,9944 \% dan 36,4998 \%. Hal tersebut menunjukkan bahwa motivasi belajar mempunyai pengaruh dominan. Sedangkan sisanya sebesar 19,4\% merupakan pengaruh dari variabel yang tidak diteliti dalam penelitian ini. Variabel tersebut dapat berupa lingkungan belajar,kesehatan fisik, keadaan keluarga, teman bermain, dan lain-lain. Namun variabel lain yang tidak ikut diteliti dalam penelitian ini juga perlu mendapat perhatian agar hasil belajar dapat lebih ditingkatkan lagi.

\section{PENUTUP}

Berdasarkan analisis data dan pembahasan mengenai motivasi belajar dan disiplin belajar terhadap hasil belajar siswa Mata Pelajaran Prakarya dan Kewirausahaan kelas X Program Keahlian Akuntansi SMK Negeri 1 Bondowoso Tahun Ajaran 2016/2017 dapat disimpulkan bahwa ada pengaruh yang signifikan motivasi belajar dan disiplin belajar terhadap hasil belajar siswa kelas $\mathrm{X}$ Program Keahlian Akuntansi SMKNegeri 1 Bondowoso Tahun Ajaran 2016/2017 yaitu sebesar $80,4 \%$. Sedangkan sisanya yaitu $19,6 \%$ dipengaruhi variabel bebas lain yang tidak diteliti yaitu lingkungan sekolah, lingkungan masyarakat, keadaan keluarga, faktor psikologis (intelegensi, perhatian, minat), dan lain-lain. Untuk pengaruh yang dominan terhadap hasil belajar siswa mata pelajaran prakarya dan kewirausahaan kelas X Program Keahlian Akuntansi SMK Negeri 1 Bondowoso Tahun Ajaran 2016/2017 yaitu pada variabel motivasi belajar (X1) sebesar 43,9944\%. Sesuai dengan hasil penelitian bahwa motivasi dan disiplin belajar memberikan konstribusi yang positif terhadap hasil belajar siswa. Oleh karena itu, motivasi belajar dan disiplin belajar perlu ditingkatkan lagi supaya hasil belajar siswa optimal. Siswa harus mempunyai motivasi belajar yang tinggi agar mereka giat belajar sehingga hasil belajar yang diperoleh optimal.

Berdasarkan hasil penelitian ini terbukti bahwa disiplin belajar sangat berpengaruh terhadap hasil belajar siswa, sehingga diharapkan para siswa mempunyai kesadaran diri akan hak dan kewajiban sebagai seorang pelajar, untuk patuh dan taat pada aturan yang diberlakukan disekolah. Peraturan dan tata tertib sekolah dibuat untuk mendisiplinkan siswa agar terbiasa hidup dengan tertib, dan teratur hingga masuk di dalam dunia kerja kelak. Untuk itu pihak sekolah sedapat mungkin lebih meningkatkan kedisiplinan siswanya, harus ada aturan yang pasti antara pihak sekolah dengan lingkungan masyarakat sekitar.

\section{DAFTAR PUSTAKA}

Farida, A. 2014. Pilar-Pilar Pembangunan Karakter Remaja. Bandung: Nuansa Cendekia. 
Hamalik, O. 2014. Psikologi Belajar Mengajar. Bandung: Sinar Baru Algensindo.

Koesoema, D. 2015. Pendidikan Karakter. Jakarta: Gramedia.

Sardiman A.M. 2014. Interaksi dan Motivasi belajar mengajar. Jakarta: PT. Raja Grafindo Persada.

Uno, Hamzah, B. 2011. Teori Motivasi dan Pengukurannya. Jakarta: PT. Bumi Aksara.

Sugiyono, 2008. Statistika Untuk Penelitian, Jakarta : Alfabeta. 